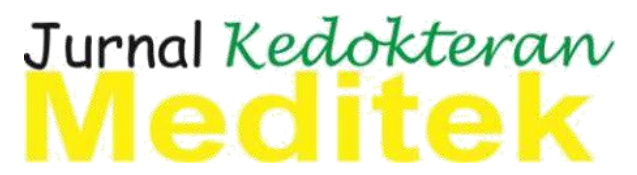

p-ISSN : 2686-1437

e-ISSN : 2686-0201

http://ejournal.ukrida.ac.id/ojs/index.php/Meditek/index

\title{
Hubungan antara Nyeri Punggung Bawah dan Durasi Duduk pada Mekanik Motor di Kalianda Lampung Selatan
}

\author{
Merlinda $^{1}$, Flora Rumiati ${ }^{2}$, Erma Mexcorry Sumbayak ${ }^{3}$ \\ ${ }^{1}$ Fakultas Kedokteran dan Ilmu Kesehatan, Universitas Kristen Krida Wacana, Jakarta, \\ Indonesia. \\ ${ }^{2}$ Departemen Fisiologi Fakultas Kedokteran dan Ilmu Kesehatan , Universitas Kristen Krida Wacana, \\ Jakarta, Indonesia. \\ ${ }^{3}$ Departemen Histopatologi Fakultas Kedokteran dan Ilmu Kesehatan, Universitas Kristen Krida \\ Wacana, Jakarta, Indonesia . \\ Alamat Korespondensi: flora.rumiati@ukrida.ac.id
}

\begin{abstract}
Abstrak
Nyeri Punggung Bawah (NPB) merupakan nyeri atau perasaan tidak nyaman yang dirasakan pada daerah di bawah margin costalis hingga ke lipat gluteal. Nyeri ini dapat bersifat lokal ataupun radikuler atau keduanya. Berdasarkan data yang diambil dari National Safety Council menyatakan bahwa NPB adalah pernyakit akibat kerja tertinggi yang terjadi dengan persentase $22 \%$ dari 1.700 .000 kasus yang ada. Penelitian ini dilakukan untuk mengetahui adanya hubungan antara lamanya duduk dengan keluhan NPB pada mekanik motor. Desain penelitian yang digunakan pada penelitian ini adalah analitik observasional potong lintang. Data diperoleh dengan membagikan kuesioner Rolland-Morris versi Bahasa Indonesia. Sebanyak 106 orang responden terpilih secara consecutive sampling dari seluruh mekanik motor yang ada di Kalianda Lampung Selatan. Angka kejadian NPB yang berhubungan dengan durasi duduk pada mekanik motor di Kalianda Lampung Selatan adalah sebanyak 37,7\%. Pada penelitian ini juga ditemukan adanya hubungan yang bermakna antara lamanya duduk dengan keluhan NPB $(\mathrm{p}<0,05)$.
\end{abstract}

Kata kunci: durasi duduk, mekanik motor, nyeri punggung bawah

\section{Relationship between Low Back Pain and Sitting Duration in Motor Mechanics Workers in Kalianda South Lampung}

\begin{abstract}
Lower Back Pain (LBP) is a pain or discomfort felt from below the costal margin to the gluteal fold. This pain can be localized or radicular or both. Based on the latest data taken from the National Safety Council, LBP is the highest work-related illness, occurring with a percentage of $22 \%$ of the 1,700,000 cases. The present study was conducted to determine the relationship between duration of sitting with LBP complaints on motor mechanics. The research design used in this study was cross-sectional observational analysis. Data was obtained by distributing the Indonesian version of the Rolland-Morris questionnaire. A total of 106 respondents were selected by a consecutive sampling from all motor mechanics in Kalianda, South Lampung. The LBP incidence associated with the duration of sitting on motor mechanics was $37.7 \%$. This study also found a significant association between duration of sitting with LBP complaints $(p<0.05)$.
\end{abstract}

Keywords: sitting duration, motor mechanics, lower back pain 


\section{Pendahuluan}

Low back pain atau nyeri punggung bawah (NPB) merupakan salah satu masalah kesehatan yang sangat umum terjadi di masyarakat. Salah satu dampak dari terjadinya NPB adalah keterbatasan seseorang dalam melakukan aktivitas sehari-harinya. Meskipun NPB merupakan penyakit yang tidak menyebabkan kematian, namun bagi individu yang mengalaminya dapat menjadi tidak produktif. Hal ini selanjutnya akan menjadi beban ekonomi bagi individu, keluarga, masyarakat, maupun pemerintah. ${ }^{1}$ Sebagian besar NPB berasal dari disfungsi muskuloskeletal, khususnya masalah mekanikal. Dalam perjalanannya, NPB dapat berkembang menjadi masalah psikologis. Gangguan muskuloskeletal sendiri merupakan gangguan yang terjadi pada otot rangka yang disebabkan karena otot menerima beban statis dalam jangka waktu yang lama secara terus menerus dan berulang, sehingga menyebabkan keluhan sakit pada sendi, ligamen serta tendon. ${ }^{2}$

Insiden NPB sendiri terjadi pada sekitar $70-85 \%$ populasi dewasa. ${ }^{3}$ Tipe yang paling sering terdapat keluhan adalah NPB nonspesifik yaitu sebesar $85-95 \%$, di mana tipe ini berhubungan dengan pekerjaan. ${ }^{3}$ Secara umum, gejala yang ditimbulkan adalah nyeri yang terasa pada lumbal atau lumbosakral, yaitu daerah diantara sudut iga terbawah sampai lipat bokong bawah. ${ }^{4}$ Gejala ini sering disertai dengan penjalaran nyeri kearah tungkai dan kaki. ${ }^{4} \mathrm{Hal}$ ini dapat disebabkan karena kelainan anatomi berupa ketidaksamaan panjang tungkai, perubahan struktur tulang belakang, spondylitis dan fraktur vertebra. ${ }^{5}$

Dari data The Global Burden of Disease 2010 Study (GBD 2010) didapatkan, dari sebanyak 291 penyakit yang diteliti, NPB adalah keluhan yang menyumbang kecacatan global terbesar, yang diukur melalui Years Lived with Disability (YLD). ${ }^{6}$ Pada penelitian yang dilakukan oleh Ruli Syukran Maulana et al didapatkan prevalensi NPB pada PNS sebesar $38,3 \%$, pekerja swasta $12,8 \%$, ibu rumah tangga $25,5 \%$, mahasiswa $10,6 \%$, dan pensiunan $12,8 \%{ }^{7}$

Prevalensi NPB di Amerika adalah antara 15-20\% dan NPB merupakan urutan kelima yang membuat pasien banyak mencari petolongan ke dokter. ${ }^{8}$ Selain itu NPB juga merupakan penyebab teratas keterbatasan dan membuat orang menjadi absen kerja. ${ }^{8}$ Menurut data dari Riset Kesehatan Dasar (Riskesdas) tahun 2013, prevalensi penyakit muskuloskeletal di Lampung adalah sebesar $18,9 \%$ dari total populasi 33 provinsi yang ada di Indonesia. ${ }^{9}$

Jenis pekerjaan yang dapat menyebabkan terjadinya NPB antara lain seperti mekanik, operator alat berat dan mesin pabrik, pegawai administrasi, pegawai keamanan, supir, dan perawat. ${ }^{10}$ Jenis alat dan sarana kerja yang kurang nyaman juga sering menimbulkan masalah bagi pekerja jika digunakan dalam jangka waktu yang lama dalam perharinya, sehingga hal ini akan menimbulkan efek negatif pada kesehatan pekerja tersebut. ${ }^{11}$

Pada mekanik motor, kegiatan yang sering dilakukan mencakup berbagai kegiatan penanganan material secara manual antara lain mendorong, menurunkan, menarik, membawa penggunaan alat-alat mekanikal serta membungkuk yang dapat menjadi penyebab terjadinya cedera ataupun penyakit akibat kerja yang mereka lakukan. ${ }^{12}$

Aktivitas yang memiliki risiko ergonomi diantaranya adalah postur tubuh yang janggal ketika melakukan pekerjaan dan melakukan gerakan berulang. ${ }^{12}$ Posisi janggal merupakan posisi tubuh yang menyimpang dari posisi tubuh yang normal yang dapat mengakibatkan peningkatan jumlah energi yang dibutuhkan saat bekerja dan hal ini juga dapat menimbulkan terjadinya kelelahan. ${ }^{12}$ Contoh posisi janggal adalah seperti jongkok, berlutut dan menjepit dengan tangan. ${ }^{13}$ Pada mekanik motor, pekerjaannya sebagian besar dilakukan sembari duduk. Posisi duduk yang paling berisiko menyebabkan terjadinya NPB adalah posisi duduk tegak dan membungkuk dengan lama 5-6 jam. ${ }^{14}$

Pada mekanik motor, dapat terlihat beberapa posisi janggal yang sering dilakukan diantaranya yaitu ketika melakukan perbaikan mesin motor, di mana letak mesin motor lebih rendah dibandingkan postur tubuh mekanik saat bekerja dan hal ini mengakibatkan timbul posisi janggal berupa duduk membungkuk sambil menyamping. Selain itu posisi janggal lainnya yang dapat ditemukan adalah posisi duduk sambil membungkuk lama untuk memperbaiki bagian-bagian mesin motor. 


\section{Metodologi Penelitian}

Disain penelitian ini adalah deskriptif analitik dalam rancangan potong lintang untuk mendapatkan hubungan antara nyeri punggung bawah dengan lama duduk dan masa kerja pada mekanik motor di Kalianda Lampung Selatan. Pendekatan yang dipilih untuk mengambil sampling adalah dengan consecutive sampling dengan responden sebanyak 106 orang yang memenuhi kriteria penelitian antara lain: merupakan pekerja mekanik motor dan pekerja yang bekerja di kawasan Kalianda Lampung Selatan. Data diperoleh melalui Roland-Morris Questionnaire berbahasa Indonesia. ${ }^{15}$ Semua subjek akan diminta persetujuan (informed consent) sebelum mengisi kuesioner. Pengambilan data ini dilaksanakan setelah lolos kaji etik dengan nomor pengajuan 591 /
SLKE-IM / UKKW / FK / KE / VIII / 2018. Pengolahan data dilakukan dengan SPSS (Statistical Product and Service Solutions) versi 25.0 .

\section{Hasil Penelitian}

Jumlah sampel dalam penelitian ini adalah 106 orang. Dari seluruh subjek yang mengalami NPB, dengan durasi lama duduk $<6$ jam sebanyak 5 orang $(19,2 \%)$, 6-9 jam sebanyak 28 orang $(41,4 \%)$, dan $>9$ jam sebanyak 7 orang $(58,3 \%)$. Responden dengan masa kerja $<4$ tahun yaitu sebanyak 13 orang $(33,3 \%)$ dan responden dengan masa kerja $>4$ tahun sebanyak 27 orang (40,3\%). Sedangkan pada responden dengan kelompok usia <25 tahun yang menderita NPB adalah sebanyak 15 orang $(44,1 \%)$ dan pada kelompok usia $>25$ tahun sebanyak 25 orang $(34,7 \%)$ (Tabel 1).

Tabel 1. Karakteristik Subjek Penelitian Pekerja Mekanik Motor

\begin{tabular}{clcccc}
\hline \multirow{2}{*}{ Variabel } & \multicolumn{2}{c}{ NPB } & \multicolumn{2}{c}{ Non-NPB } \\
\cline { 3 - 6 } & & $\mathrm{N}$ & $\%$ & $\mathrm{~N}$ & $\%$ \\
\hline \multirow{2}{*}{ Lama Duduk } & $6-9$ jam & 28 & $41,1 \%$ & 40 & $58,9 \%$ \\
& $>9$ jam & 7 & $58,3 \%$ & 5 & $41,7 \%$ \\
\multirow{2}{*}{ Masa Kerja } & $<4$ tahun & 13 & $33,3 \%$ & 26 & $66,7 \%$ \\
& $>4$ tahun & 27 & $40,3 \%$ & 40 & $59,7 \%$ \\
\multirow{2}{*}{ Usia } & $<25$ tahun & 15 & $44,1 \%$ & 19 & $55,9 \%$ \\
& $>25$ tahun & 25 & $34,7 \%$ & 47 & $65,3 \%$ \\
\hline
\end{tabular}

Berdasarkan hasil penelitian didapatkan responden dengan kelompok usia $<25$ tahun dengan masa kerja $>4$ tahun lebih tinggi yaitu sebanyak 24 orang $(70,6 \%)$ jika dibandingkan dengan responden yang berusia $>25$ tahun dengan masa kerja $>4$ tahun sebanyak 43 orang $(59,3 \%)$ (Tabel 2). 
Tabel 2. Distribusi Usia terhadap Masa Kerja pada Mekanik Motor di Kalianda Lampung Selatan

\begin{tabular}{cccc}
\hline \multirow{2}{*}{ Usia } & & \multicolumn{2}{c}{ Masa Kerja } \\
\cline { 3 - 4 } & & $<4$ tahun & $>4$ tahun \\
\hline \multirow{2}{*}{$<25$ tahun } & $\mathrm{N}$ & 10 & 24 \\
& $\%$ & $29,4 \%$ & $70,6 \%$ \\
& $\mathrm{~N}$ & 29 & 43 \\
\hline \multirow{2}{*}{$>25$ tahun } & $\%$ & $40,3 \%$ & $59,3 \%$ \\
\hline
\end{tabular}

Pada Tabel 3 dapat dilihat bahwa responden dengan kelompok usia $<25$ tahun memiliki durasi duduk 6-9 jam per harinya sebanyak 25 orang $(73,5 \%)$. Persentase pada kelompok umur ini terhadap lama duduk, memiliki persentase tertinggi jika dibandingkan dengan reponden berusia $>25$ tahun.

Tabel 3. Distribusi Usia terhadap Durasi Duduk pada Mekanik Motor di Kalianda Lampung Selatan

\begin{tabular}{ccccc}
\hline \multirow{2}{*}{ Usia } & & \multicolumn{3}{c}{ Lama Duduk } \\
\cline { 2 - 5 } & & $<6$ jam & $6-9$ jam & $>9$ jam \\
\hline \multirow{2}{*}{$<25$ tahun } & $\mathrm{N}$ & 6 & 25 & 3 \\
& $\%$ & $17,6 \%$ & $73,5 \%$ & $8,8 \%$ \\
& $\mathrm{~N}$ & 20 & 43 & 9 \\
\hline \multirow{2}{*}{$>25$ tahun } & $\%$ & $27,8 \%$ & $59,7 \%$ & $12,5 \%$ \\
\hline
\end{tabular}

Tabel 4. Analisis Hubungan Antara Durasi Duduk dengan Keluhan LBP pada Mekanik Motor di Kalianda Lampung Selatan

\begin{tabular}{|c|c|c|c|c|c|c|}
\hline \multirow{2}{*}{\multicolumn{2}{|c|}{ Durasi Duduk }} & \multicolumn{2}{|c|}{ Keluhan NPB } & \multirow{3}{*}{$\begin{array}{c}\text { Total } \\
26\end{array}$} & \multirow{2}{*}{$P$ Value } & \multirow{2}{*}{$\begin{array}{c}\text { Odd Ratio } \\
\left(\mathbf{X}^{2}\right)\end{array}$} \\
\hline & & NPB & Non-NPB & & & \\
\hline \multirow{2}{*}{$<6$ jam } & $\mathrm{N}$ & 5 & 21 & & \multirow{7}{*}{,043 } & \multirow{3}{*}{0,34} \\
\hline & $\%$ & $19,2 \%$ & $80,8 \%$ & $100,0 \%$ & & \\
\hline \multirow{2}{*}{ 6-9 jam } & $\mathrm{N}$ & 28 & 40 & 68 & & \\
\hline & $\%$ & $41,2 \%$ & $58,8 \%$ & $100,0 \%$ & & \multirow{4}{*}{0,50} \\
\hline \multirow{2}{*}{$>9$ jam } & $\mathrm{N}$ & 7 & 5 & 12 & & \\
\hline & $\%$ & $58,3 \%$ & $41,7 \%$ & $100,0 \%$ & & \\
\hline \multirow{2}{*}{ Total } & $\mathrm{N}$ & 40 & 66 & 106 & & \\
\hline & $\%$ & $37,7 \%$ & $62,3 \%$ & $100,0 \%$ & & \\
\hline
\end{tabular}




\section{Pembahasan}

Hasil penelitian terhadap 106 orang sampel didapatkan bahwa jumlah tertinggi pada durasi duduk adalah pada lama duduk $>9$ jam sebanyak 7 orang $(58,3 \%)$. Hal ini sejalan dengan penelitian yang dilakukan oleh Van Der Ploeg et $a l$, yang menyatakan bahwa orang yang duduk >9 jam per hari diklasifikasikan sebagai duduk terlalu lama yang merupakan salah satu predisposisi terjadinya NPB. Sedangkan untuk lama duduk $<6$ jam dalam sehari, pada penelitian tersebut dianggap normal. ${ }^{16}$

Pada penelitian yang dilakukan, didapatkan masa kerja tertinggi yaitu pada responden dengan masa kerja $>4$ tahun sebanyak 27 orang $(40,3 \%)$. Hasil ini sejalan dengan penelitian yang dilakukan oleh Sari pada tahun 2017 bahwa pada responden dengan masa kerja $>4$ tahun memiliki jumlah terjadinya keluhan NPB lebih besar 63,2\% jika dibandingkan dengan pekerja yang memiliki masa kerja $<4$ tahun yaitu sebesar 36,8\%. ${ }^{17}$

Masa kerja dapat meningkatkan risiko terjadinya NPB, karena masa kerja memiliki hubungan yang kuat dengan keluhan otot. Masa kerja yang lama berpengaruh terhadap pembebanan pada otot dan tulang. Pekerja yang memiliki masa kerja yang cukup lama akan membuat gerakan yang sama dan berulang sehingga hal inilah yang menjadi pemicu terjadinya kelelahan jaringan dan spasme otot. Selain itu semakin lama masa kerja seseorang maka akan terjadi juga penurunan kinerja pada otot mereka. Keluhan NPB adalah gejala kronis yang membutuhkan waktu tidak singkat untuk perkembangan perjalanan penyakit. ${ }^{11,18}$

Menurut teori, usia merupakan salah satu faktor yang dapat menyebabkan terjadinya keluhan NPB. Pada umumnya, keluhan pertama NPB biasanya dimulai pada usia 35 tahun dan tingkat keluhan akan semakin meningkat semakin bertambahnya usia. ${ }^{19}$ Kekuatan otot maksimal terjadi pada rentang usia 20-29 tahun dan selanjutnya akan terus terjadi penurunan seiring bertambahnya umur. ${ }^{19}$ Hal ini disebabkan karena sejalan dengan bertambahnya usia maka akan terjadi penurunan fungsi dalam sistem tubuh manusia dan salah satunya adalah pada sistem muskuloskeletal. ${ }^{12}$ Mulai usia 30 tahun akan terjadi degenerasi tulang, yaitu berupa kerusakan pada jaringan, penggantian jaringan menjadi jaringan parut (fibrosis), dan pengurangan cairan. ${ }^{20}$ Sehingga hal ini menyebabkan stabilitas pada tulang dan otot menjadi berkurang. Selain itu akan terjadi juga penurunan elastisitas diskus invertebralis pada tulang belakang yang disebabkan karena degenerasi nukleus pulposus yang berfungsi sebagai bantalan dan mobilitas pada tulang belakang. ${ }^{20}$

Namun pada penelitian ini didapatkan bahwa jumlah tertinggi pekerja yang mengalami NPB adalah pada kelompok usia $<25$ tahun yaitu sebanyak 15 orang $(44,1 \%)$. Hal ini disebabkan karena perbedaan masa kerja dan durasi lama duduk yang signifikan (lihat Tabel 2 dan 3) pada kedua kelompok usia responden ini. Hasil pada responden dengan kelompok usia $<25$ tahun memiliki masa kerja $>4$ tahun lebih tinggi yaitu sebanyak 24 orang $(70,6 \%)$ dibandingkan dengan responden dengan kelompok usia $<25$ tahun. Selain itu juga durasi lama duduk pada responden $<25$ tahun yang dapat meningkatkan risiko terjadinya NPB adalah duduk $>6$ jam. Dari penelitian ini didapatkan sebanyak 25 orang $(73,5 \%)$ memiliki durasi lama duduk 6-9 jam dan 3 orang $(8,8 \%)$ pada lama duduk $>9$ jam. Selain itu juga, hal yang dapat menyebabkan tingginya jumlah keluhan NPB pada kelompok usia $<25$ ini adalah mungkin karena beban kerja dan sikap tidak ergonomis yang responden lakukan pada saat bekerja.

\section{Hubungan antara Durasi Duduk dengan Keluhan NPB}

Dari hasil analisis data penelitian menggunakan uji chi-square pada tabel 4 didapatkan hasil $\mathrm{P}$ value sebesar 0,043 ( $\mathrm{p}<$ $0,05)$. Sehingga dari penelitian ini dapat disimpulkan bahwa terdapat hubungan yang bermakna antara durasi duduk dengan keluhan NPB pada mekanik motor di Kalianda Lampung Selatan. Responden dengan lama duduk 6-9 jam memiliki nilai Odds Ratio (OR) 0,34 yang artinya orang dengan lama duduk 6-9 jam memiliki risiko 0,34 kali lebih besar dibandingkan orang yang hanya duduk $<6$ jam per hari selama bekerja; dan pada responden dengan lama duduk $>9$ jam memiliki nilai OR 0,50 yang artinya pekerja dengan lama duduk $>9$ jam per hari memiliki risiko 0,50 kali lebih besar mengalami keluhan NPB jika dibandingkan dengan pekerja yang hanya duduk selama 6-9 jam.

Hasil penelitian ini sejalan dengan penelitian yang dilakukan oleh Sari et al pada tahun 2015 yaitu didapatkan adanya hubungan 
yang bermakna antara lamanya duduk dengan keluhan NPB. ${ }^{21}$ Hal ini disebabkan karena semakin lama durasi seseorang duduk, akan terjadi ketegangan pada otot sekitar pungung serta ligamentum punggung akan meregang, khususnya pada ligamentum posterior setinggi L2-L5 yang merupakan ligamentum paling tipis diantara ligamentum lainnya. ${ }^{7} \mathrm{Hal}$ ini lebih sering menyebabkan terjadinya keluhan nyeri akibat iskemia jaringan. ${ }^{7}$ Selain itu, otot yang dalam jangka waktu lama mengalami kontraksi secara terus menerus, dapat mengalami kekurangan darah yang diakibatkan karena pembuluh darah yang terjepit. ${ }^{22,23} \mathrm{Hal}$ tersebut selanjutnya mengakibatkan otot menjadi kekurangan oksigen serta berkurangnya pembentukan energi dan terjadi pembentukan asam laktat, sehingga otot menjadi cepat lelah dan timbul rasa nyeri. ${ }^{22,23}$

\section{Simpulan}

Gambaran NPB terhadap variabel yang diteliti (lama duduk, masa kerja, dan usia) pada mekanik motor di Kalianda Lampung Selatan adalah $37,7 \%$. Adanya hubungan yang bermakna antara lamanya duduk dengan kejadian NPB pada mekanik motor di Kalianda Lampung Selatan, dimana semakin lama duduk dapat menyebabkan meningkatnya keluhan NPB.

\section{Daftar Pustaka}

1. Hoy D, March L, Brooks P, Blyth F, Woolf A, Baik C, et al. The global burden of low back pain: estimates from the global burden of disease 2010 study. Ann Rheum Dis. 2014;73(6): 968-74.

2. Umami AR, Hartanti RI, Dewi A. Hubungan antara karakteristik responden dan sikap kerja duduk dengan keluhan nyeri punggung bawah (low back pain) pada pekerja batik tulis. E-Jurnal Pustaka Kesehatan. 2014;1(2): 73.

3. Syamsiah IR, Djojosugito MA, Argadireja DS. Hubungan posisi duduk dan lama duduk dengan kejadian nyeri punggung bawah pada pegawai administrasi Universitas Islam Bandung tahun 2017. Prosiding Pendidikan Dokter. 2017;3(1): 339-45.

4. Andini F. Risk factors of low back pain in workers. J Majority. 2015;4(1): 13.

5. Putra RS, Legiran, Azhar MB. Hubungan posisi duduk dan ketidaksesuaian desain tempat duduk sepeda motor dengan kejadian nyeri pinggang pada pengendara ojek daring. Majalah Kedokteran Sriwijaya. 2018;2: 75.

6. Patrianingrum $\mathrm{M}$, Oktaliansah E, Suharman E. Prevalensi dan faktor risiko nyeri punggung bawah di lingkungan kerja anestesiologi rumah sakit dr. Hasan Sadikin Bandung. Jurnal Anestesi Perioperatif. 2015;3(1): 47-56.

7. Maulana RS, Mutiawati E, Azmunir. Hubungan indeks massa tubuh (IMT) dengan tingkat nyeri pada penderita low back pain (LBP) di poliklinik saraf RSUD dr. Zainoel Abidin Banda Aceh. Jurnal Ilmiah Mahasiswa Kedokteran Biomedis. 2016;1(4): 2-5.

8. Santosa A, Widyadharma IPE, Purwata TE. Korelasi lama duduk dengan nyeri punggung bawah pada pekerja hotel the Grand Santhi Denpasar. E-Jurnal Medika. 2016;5(10): 1-5.

9. Badan Penelitian dan Pengembangan Kesehatan Kementrian Kesehatan RI. Riset Kesehatan Dasar 2013. 2013. Diunduh dari: http://www.depkes.go.id/resources/downl oad/general/Hasil\%20Riskesdas\%202013 .pdf. 10 Desember 2018.

10. Nurazizah S, Widayanti, Rukanta D. Hubungan kebiasaan olahraga dengan low back pain disability. SpeSia. 2015: 968-74.

11. Koesyanto H. Masa kerja dan sikap kerja duduk terhadap nyeri punggung. Jurnal Kesehatan Masyarakat. 2013;9(1): 9-14.

12. Adzhani AR, Ekawati, Jayanti S. Analisis postur kerja pada mekanik bengkel sepeda motor hidrolik x dan non-hidrolik y kota Semarang. Jurnal Kesehatan Masyarakat. 2016; 4(3): 283.

13. Andini F. Risk factors of low back pain in workers. J Majority. 2015;4(1):12-9.

14. Kuswana ES. Ergonomi dan K3. Bandung: Remaja Rosdakarya; 2014.

15. Widiasih G. Hubungan posisi belajar dan lama duduk dengan kejadian nyeri punggung bawah mahasiswa pspd fkik uin jakarta. Skripsi: Universitas Islam Negri; 2015.

16. Van Der Ploeg HP, Chey T, Korda J, Banks E, Bauman A. Sitting time and all cause mortality risk in 222497 Australian 
adults. Arch Intern Med. 2012;172(6).

17. Sari RT. Hubungan sikap kerja dan masa kerja dengan keluhan nyeri punggung bawah pada pekerja industri rumah tangga rambak kering desa Doplang kecamatan Teras Boyolali. Skripsi: Universitas Muhammadiyah Surakarta; 2017.

18. Sulaeman YA, Kunaefi TD. Low back pain (LBP) pada pekerja di divisi minuman tradisional (studi kasus CV. Cihanjung Inti Teknik). Jurnal Teknik Lingkungan. 2015;21(2): 201-11.

19. Amila, Sembiring E, Siregar R. Nyeri punggung bawah pada perawat IGD dan ICU RSU Sari Mutiara Medan. Jurnal INJEC. 2015;2(2): 246-52.

20. Hadyan MF, Saftarina F. Hubungan usia, lama kerja, masa kerja dan indeks massa tubuh (IMT) terhadap kejadian low back pain (LBP) pada petani di desa Munca kabupaten Pesawaran. Jurnal Medula. 2017;7(4): 141-6.

21. Sari NPLNI, Mogi TI, Angliadi E. Hubungan lama duduk dengan kejadian low back pain pada operator komputer perusahaan travel di manado. Jurnal eClinic. 2015;3(2): 693.

22. Sumekar WD, Natalia D. Computer operator's low back pain caused by sitting position and duration. MKB. 2010;42(3): 123-7.

23. Wahyuni LGASN, Winaya IMN, Primayanti IDAID. Sikap duduk ergonomis mengurangi nyeri punggung bawah non spesifik pada mahasiswa program studi fisioterapi fakultas kedokteran Universitas Udayana. Majalah Ilmiah Fisioterapi Indonesia. 2016;2(1): 15-8. 